360 to 120. Anhui Province carried out an investigation studying the alligator's calls and behaviour. They found that typically one male stayed in one cave together with one, two, or even four or five females.

Alligators are clearly decreasing, due not only to loss of habitat, but also because there has been insufficient propaganda and education. People have been allowed to believe that they are harmful to fish farming and duck rearing and have killed them freely, and children, knowing nothing about protecting rare animals, smash the eggs in the breeding season. Moreover, the large quantities of agricultural pesticides and chemical fertilisers used in recent years have destroyed the alligators' food resources and thus menaced their survival. These factors have long eluded a solution.

\title{
Moorhens for Malta
}

\section{Bill and Sheila Bourne}

The slaughter and capture of hundreds of millions of migrating north European birds in the Mediterranean region have long been a major conservation problem. The worst havoc is in Malta, which subscribes to none of the bird protection conventions, and where the main recreation is to shoot anything large enough to stuff, and to catch anything smaller and put it in a cage.

During the 1980 conference of the European Continental Section of ICBP (the International Council for Bird Preservation) a few of us walked up on to a bare headland one fine morning. The countryside echoed to the song of finches, but only sparrows could be seen because the finches were sitting in little cages set out around clap-nets so that the lonely birds could call their relatives down to join them in captivity. Within one square mile there must have been hundreds of trapping sites, of which about a quarter were in use. Many local people, we were told to take their holidays at this season to go bird-catching. Later at an early Sunday morning market in Valletta we saw dozens of call birds crammed into small cages piled under sacks on the ground and in the backs of vans. The birds for sale included over 500 linnets, which sell for about $£ M 1$ each, serins ( $£ M 2$ ), several hundred chaffinches and bramblings ( $£ M 2-3$ ), goldfinches (£M5-6), greenfinches (£M10) and occasional haw finches $(\boldsymbol{E} M 20-30)$. On a market stall were dozens of starlings, sky and calandra larks, collared doves and quail, and probably also in the vans golden plover, which fetch high prices. Prices were said to be twice as high at other times of year, attracting illegal imports from Sicily and Tunisia, and leading to increased trapping there.

For the larger species the treatment is different. In the past the whole countryside was continually quartered by shooters. At the best wood, at Buskett in the centre of the island, now declared a reserve, we were told how earlier in the autumn hundreds of hunters would wait at dusk to shoot the birds of prey as they flew in to roost. In one evening last year this accounted for over 40 honey buzzards, several harriers and kestrels, two kites, a peregrine, a red-footed falcon, and one or two Eleonora's falcons. We

CALL BIRDS

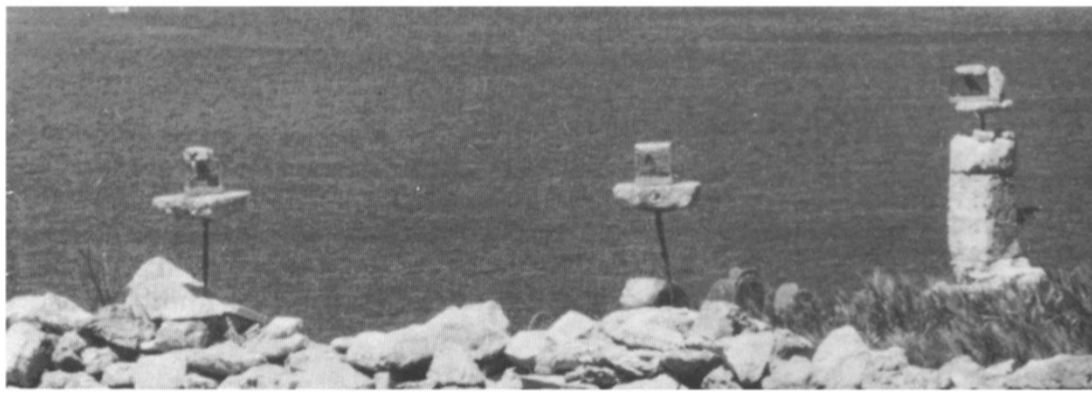




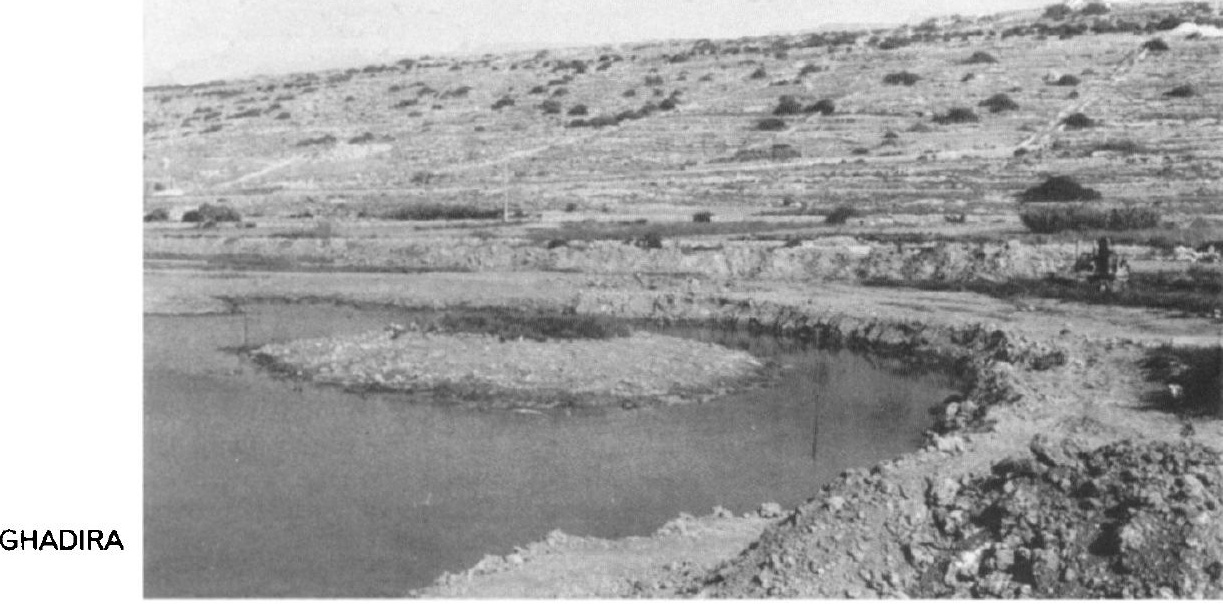

could see and hear several shooters in action at the time. It has become increasingly fashionable to make private collections of the stuffed birds.

The President of Malta, Dr Anton Buttigieg, told the Conference that in 1971 , as Minister of Justice, he was prevented by local vested interests from introducing conservation legislation. The chairman of the local ornithological society, Joe Sultana, and a policemen, Joe Attard, started an educational campaign involving young people. This was received with great hostility at first, but with assistance from the Banbury Ornithological Society in England, led by Betty Coxon, is now a vigorous body of some 650 members, about a quarter overseas, including many young people. In August 1980 new legislation for the first time imposed a close season for shooting and trapping (May 22 - August 31 ), restricted the species, and limited and prohibited hunting around a number of reserves and out at sea. It still leaves much to be desired, but the overworked police are taking vigorous action, and have impounded thousands of pounds' worth of shotguns.

Meanwhile a committee set up by the Department of Health and Environment has begun to convert the best seasonal pool, Ghadira, into a National Reserve. On the advice of Bert Axell, who created the famous RSPB reserve at Minsmere, and with a $£$ M 9000 WWF grant they have already deepened and diversified the pool, constructed a defensive ditch and bank, and erected a central stone observation post. This year the European Committee for the Prevention of Destruction of Migratory Birds has given them $£ M 2000$ for the further enlargement of the pool, and the Mid Med Bank £M3000 for the construction of an educational hall and store. They still need $£ 30,000$ to complete the project.

In his talk to the Conference Joe Sultana described how the only moorhen that he had ever seen in Malta, where it is regarded as a mysterious dark stranger, was blown apart by twelve simultaneous shots as it fled from the bush at Ghadira where it had tried to hide. On the last morning of the conference another moorhen was found hiding in a drain; this one was ringed and released. Perhaps one day soon the first young moorhens in many centuries will hatch in Malta, and Maltese will put away their guns for good.

A full report on Bird Killing in the Mediterranean by Dr S Woldhek is obtainable from the Migratory Birds Committee, WWF Panda House, 11-13 Ockford Rd, Godalming, Surrey, $£ 3.50$, which also accepts donations. The Ornithological Society, PO Box 498, Valletta, Malta, welcomes foreign members, who receive their publications describing progress.

Department of Zoology, Tillydrone Avenue, Aberdeen AB9 2TN. 